\title{
Character Association and Path Coefficient Analysis in African Marigold (Tagetes erecta L.)
}

\author{
Jitendra Kumar Sahu ${ }^{1^{*}}$, Gaurav Sharma ${ }^{1}$, S. K. Nair ${ }^{2}$ and Neelima Netam ${ }^{1}$ \\ ${ }^{1}$ Dept. of Floriculture and Landscape Architecture 2Dept. of Genetics and Plant Breeding Indira Gandhi Krishi Vishwavidyalaya, \\ Raipur, Chhattisgarh (492 012), India
}

\author{
Corresponding Author \\ Jitendra Kumar Sahu \\ e-mail: sahujitendra11@gmail.com
}

\author{
Article History \\ Article ID: 3 C0562 \\ Received in $24^{\text {th }}$ October, 2017 \\ Received in revised form $26^{\text {th }}$ April, 2018 \\ Accepted in final form $28^{\text {th }}$ May, 2018
}

\begin{abstract}
The present investigation entitled was conducted at the Horticultural Research cum Instructional Farm, Department of Floriculture and Landscape Architecture, Indira Gandhi Krishi Vishwavidyalaya, Raipur (C.G.) during the year 2015 to study the performance of seventeen African marigold genotypes in Randomized Block Design replicated three times. Considerable variability for most of the characters was indicated by analysis of variance. Association among different characters was estimated at genotypic $(G)$ and phenotypic $(P)$ levels among 13 characters. Number of flowers plant ${ }^{-1}$ exerted highly significant positive correlation with fresh flower weight plant ${ }^{-1}$ (yield plant ${ }^{-1}$ ), dry $^{-1}$ flower weight plant ${ }^{-1}$, flower yield hectare ${ }^{-1}$ and xanthophyll content at genotypic and phenotypic level and significantly positive association with flower diameter at genotypic level only. The path-coefficient analysis revealed that, at genotypic level, fresh flower weight plant ${ }^{-1}$ expressed highest positive direct effect on number of flowers plant ${ }^{-1}$ followed by xanthophyll content, plant height, plant spread and secondary branches. Although yield hectare ${ }^{-1}$ shows highly significant positive correlation with number of flowers plant ${ }^{-1}$. At phenotypic level, fresh flower weight plant ${ }^{-1}$ showed high positive direct effect on number of flowers plant ${ }^{-1}$ followed by plant spread, number of secondary branches plant ${ }^{-1}$ and days to $50 \%$ flowering.
\end{abstract}

Keywords: African marigold, Character association, path analysis, flower yield, xanthophyll

\section{Introduction}

Marigold (Tagetes erecta L.) is one of the important commercial annual flower crop belonging to the family Asteraceae. African marigold is popular throughout the world because of wide spectrum of attractive colours, shape and good keeping quality has attracted the attention of flower growers. They are extensively used as loose flower, potted plant and also as a bedding plant. It has gained popularity in India on account of its easy cultivation, wide adaptability and production throughout the year. In Chhattisgarh, also marigold is one of the dominating flowers which fetches high price in the local market. Moreover, looking to the diverse marigold available in the different agro-climatic condition of Chhattisgarh, there is a scope of finding remarkable variations in the growth, flowering and xanthophyll content in the locally available marigold flowers. Yield is a complex character controlled by a large number of contributing characters and their interactions. A study of correlation between different quantitative characters provides an idea of association that could be effectively exploited to formulate selection strategies for improving yield components. It is essential to know the degree of mutual association (correlation) prevailing between yield and its component characters, which forms a basis for selecting the desirable genotypes. The analysis of inter componential correlation is very essential to expose the direct and indirect contribution of each of the components which is determined by path coefficient. On the basis of these studies, the importance of individual character is marked to facilitate the selection programme for better gains. Correlation analysis indicated that the flower yield plant ${ }^{-1}$ was found to be significantly and positively correlated with number of branches plant $^{-1}$, flower size, flower weight, number of flowers plant ${ }^{-1}$ and xanthophylls content (Karuppaiah et al., 2010). Path analysis has shown that number of flowers per hectare had high positive direct effect with plant height at 120 DAT (0.962), number of days taken to first flowering (0.646), flower weight (1.034), stalk length (0.253), number of tubers plant ${ }^{-1}(0.353)$, tuber weight (0.194) and vase life (0.285) at genotypic level. Thus, these characters have maximum contribution towards the number of flowers per hectare. (Manjula and Nataraj, 2016.). According to Usha Bharti et al. (2014) The path analysis indicated that total duration, number of flowers plant ${ }^{-1}$, flower size, single flower weight and number of harvest plant ${ }^{-1}$ had maximum direct effect. According to Gobade et al. (2017) Genetic variability and heritability studies indicated that there 
were highly significant differences between the genotypes for yield of flower ha-1 and eighteen other characters. Kavitha and Anburani (2010) studied the genetic variability present in thirty germplasm of marigold. The coefficients of variation both at genotypic and phenotypic levels were maximum for number of flowers plant ${ }^{-1}$, while minimum 12 for dry matter production. Heritability estimates for all the characters were generally very high. High heritability along with high genetic advance as per cent of mean was observed for number of flowers plant ${ }^{-1}$. Flower yield plant ${ }^{-1}$ and number of laterals plant $^{-1}$ was due to additive gene effects thus suggesting that selection for these characters would be very effective.

Anuja and Jahnavi (2012) studied genotypic and phenotypic correlations and path-coefficient analysis for seven characters in French marigold. Plant height, stem girth, number of branches plant ${ }^{-1}$, days to first flowering, flower head diameter, flower head weight and number of flowers plant ${ }^{-1}$. The correlation studies revealed that stem girth, flower head diameter and number of flowers plant ${ }^{-1}$ were found to be positively correlated with flower yield.

According to Kumar et al. (2014) The yield of flowers plant ${ }^{-1}$ exhibited highly significant and positive correlation with number of primary branches (0.862), number of secondary branches (0.738), number of flowers plant ${ }^{-1}(0.862)$ and flower weight (0.732). Hence, these characters should be given due consideration during selection for yield improvement in French marigold.

Comparison of genotypic and phenotypic co-efficient of variation for different traits indicated that the values of PCV were higher as compared to GCV due to the influence of environment. The coefficient of variation both at genotypic and phenotypic levels were maximum for disc diameter, yield of flowers ha-1, weight of flower, diameter of fully opened flower, shelf life, number of flower plant ${ }^{-1}$ and length of pedicel. Heritability estimates for all the characters except plant spread at $50 \%$ flowering were high. High heritability along with high genetic advance as per cent of mean was observed for disc diameter, yield of flowers ha-1, weight of flower, diameter of fully opened flower, number of flowers plant $^{-1}$, shelf life, and length of pedicel which were due to additive gene effects thus suggesting that selection for these characters would be very effective.

\section{Materials and Methods}

The present investigation was conducted at the Horticultural Research cum Instruction Farm of the Department of Floriculture and Landscape Architecture, College of Agriculture, Indira Gandhi KrishiVishwavidyalaya, Raipur, Chhattisgarh during the year 2015. The treatment consisted of seventeen genotypes of African marigold collected from diverse sources were used for present study. The experimental field was laid out in Randomized Block Design with three replications. The seeds of all the genotypes were sown in the nursery beds to raise seedlings and transplanting was done after 23 days of sowing with spacing of $40 \times 40 \mathrm{~cm}^{2}$ between rows and plants within a row. The observations were recorded on five random competitive plants from each replication after discarding the border plants. The genotypes were assessed and observations were recorded for various growth and flowering related traits viz. plant height $(\mathrm{cm})$, plant spread $(\mathrm{cm})$, number of primary branches plant ${ }^{-1}$, number of secondary branches per plant, number of leaves per plant, days to $50 \%$ flowering, number of flowers per plant, flower diameter $(\mathrm{cm})$, flower yield plant ${ }^{-1}$ $(\mathrm{kg})$, dry flower weight plant ${ }^{-1}(\mathrm{~kg})$, flowering duration (days), xanthophyll content.

\section{Results and Discussion}

\subsection{Character association}

Association among different characters was estimated at genotypic $(\mathrm{G})$ and phenotypic $(\mathrm{P})$ levels among 13 characters and is presented in Table 1. Number of flowers plant ${ }^{-1}$ exerted highly significant positive correlation with fresh flower weight plant ${ }^{-1}$ (yield plant ${ }^{-1}$ ), dry flower weight plant ${ }^{-1}$, flower yield hectare ${ }^{-1}$ and xanthophyll content at genotypic and phenotypic level and significantly positive association with flower diameter at genotypic level only. Plant height had highly positive significant association with number of primary branches plant ${ }^{-1}$ and number of leaves plant ${ }^{-1}$ at genotypic and phenotypic level. While number of secondary branches plant ${ }^{-1}$ and days to $50 \%$ flowering were highly positive significant at only genotypic level but significant at phenotypic level. Significant positive association of plant spread was recorded with days to $50 \%$ flowering at genotypic and phenotypic level. Highly significant positive association of number of primary branches plant ${ }^{-1}$ was recorded with number of secondary branches plant ${ }^{-1}$, number of leaves plant ${ }^{-1}$, fresh flower weight plant ${ }^{-1}$ and dry flower weight plant ${ }^{-1}$ and flower yield hectare ${ }^{-1}$ at genotypic and phenotypic level while highly significant association with flowering duration at genotypic level and significant association at phenotypic level. Number of secondary branches plant ${ }^{-1}$ showed highly significant and positive correlation with number of leaves plant $^{-1}$, fresh flower weight plant ${ }^{-1}$, dry flower weight plant ${ }^{-1}$ and flower yield ha ${ }^{-1}$ at both genotypic and phenotypic level. Number of leaves plant ${ }^{-1}$ showed highly significant and positive correlation with fresh flower weight plant ${ }^{-1}$, dry flower weight plant $^{-1}$, flowering duration and flower yield ha-1 at genotypic and phenotypic levels. Diameter of flower exerted highly significant positive association with dry flower weight plant $^{-1}$ and significant positive correlation with fresh flower weight plant $^{-1}$, flower yield ha-1 and xanthophyll content at genotypic level only. Whereas, at phenotypic level significant positive correlation was observed with fresh weight of flowers plant ${ }^{-1}$. Fresh flower weight plant ${ }^{-1}$ exerted highly significant positive correlation with dry flower weight plant ${ }^{-1}$, flower yield ha-1 and xanthophyll content at genotypic and phenotypic level, while fro duration of flowering, highly significant positive correlation 


\begin{tabular}{|c|c|c|c|c|c|c|c|c|c|c|c|c|c|}
\hline & & 2 & 3 & 4 & 5 & 6 & 7 & 8 & 9 & 10 & 11 & 12 & 13 \\
\hline \multirow[t]{2}{*}{1} & G & -0.268 & $0.440^{* *}$ & $0.372^{* *}$ & $0.489^{* *}$ & $0.354^{* *}$ & $-0.518^{* *}$ & $0.305^{*}$ & -0.229 & -0.134 & 0.164 & -0.230 & -0.106 \\
\hline & $\mathrm{P}$ & -0.225 & $0.412^{* *}$ & $0.343^{*}$ & $0.451^{* *}$ & $0.287^{*}$ & $-0.488^{* *}$ & $0.292^{*}$ & -0.212 & -0.129 & 0.174 & -0.213 & -0.104 \\
\hline \multirow[t]{2}{*}{2} & G & & -0.109 & 0.075 & 0.070 & $0.285^{*}$ & 0.122 & $-0.352^{* *}$ & 0.056 & 0.140 & -0.020 & 0.055 & -0.135 \\
\hline & $\mathrm{P}$ & & -0.136 & 0.045 & 0.058 & $0.289^{*}$ & 0.099 & -0.222 & 0.056 & 0.124 & -0.001 & 0.061 & -0.126 \\
\hline \multirow[t]{2}{*}{3} & G & & & $0.646^{* *}$ & $0.743^{* *}$ & 0.141 & -0.007 & 0.256 & $0.469^{* *}$ & $0.391^{* *}$ & $0.367^{* *}$ & $0.470^{* *}$ & 0.122 \\
\hline & $P$ & & & $0.594^{* *}$ & $0.693^{* *}$ & 0.101 & -0.005 & 0.181 & $0.419^{* *}$ & $0.368^{* *}$ & $0.320^{*}$ & $0.415^{* *}$ & 0.115 \\
\hline \multirow[t]{2}{*}{4} & G & & & & $0.744^{* *}$ & 0.108 & 0.105 & 0.172 & $0.489^{* *}$ & $0.513^{* *}$ & 0.239 & $0.491^{* *}$ & 0.040 \\
\hline & $P$ & & & & $0.693^{* *}$ & 0.115 & 0.100 & 0.110 & $0.459^{* *}$ & $0.479^{* *}$ & 0.202 & $0.455^{* *}$ & 0.040 \\
\hline \multirow[t]{2}{*}{5} & G & & & & & 0.080 & -0.169 & -0.063 & $0.461^{* *}$ & $0.481^{* *}$ & $0.506^{* *}$ & $0.462^{* *}$ & 0.014 \\
\hline & $P$ & & & & & 0.046 & -0.163 & -0.037 & $0.430^{* *}$ & $0.461^{* *}$ & $0.459^{* *}$ & $0.426^{* *}$ & 0.012 \\
\hline \multirow[t]{2}{*}{6} & G & & & & & & $-0.346^{*}$ & $-0.440^{* *}$ & $-0.464^{* *}$ & $-0.399^{* *}$ & -0.075 & $-0.463^{* *}$ & -0.146 \\
\hline & $P$ & & & & & & -0.257 & $-0.289^{*}$ & $-0.342^{*}$ & $-0.318^{*}$ & 0.033 & $-0.343^{*}$ & -0.115 \\
\hline \multirow[t]{2}{*}{7} & G & & & & & & & $0.287^{*}$ & $0.626^{* *}$ & $0.434^{* *}$ & -0.171 & $0.630^{* *}$ & $0.504^{* *}$ \\
\hline & $P$ & & & & & & & 0.214 & $0.625^{* *}$ & $0.441^{* *}$ & -0.152 & $0.618^{* *}$ & $0.491^{* *}$ \\
\hline \multirow[t]{2}{*}{8} & G & & & & & & & & $0.320^{*}$ & $0.380^{* *}$ & -0.163 & $0.316^{*}$ & $0.300^{*}$ \\
\hline & $P$ & & & & & & & & 0.256 & $0.327^{*}$ & -0.114 & 0.263 & 0.247 \\
\hline \multirow[t]{2}{*}{9} & G & & & & & & & & & $0.929^{* *}$ & $0.370^{* *}$ & $1.002^{* *}$ & $0.399^{* *}$ \\
\hline & $P$ & & & & & & & & & $0.906^{* *}$ & $0.349^{*}$ & $0.996^{* *}$ & $0.388^{* *}$ \\
\hline \multirow[t]{2}{*}{10} & G & & & & & & & & & & $0.344^{*}$ & $0.933^{* *}$ & 0.243 \\
\hline & $P$ & & & & & & & & & & $0.319^{*}$ & $0.899^{* *}$ & 0.240 \\
\hline \multirow[t]{2}{*}{11} & G & & & & & & & & & & & $0.372^{* *}$ & $0.439^{* *}$ \\
\hline & $\mathrm{P}$ & & & & & & & & & & & $0.344^{*}$ & $0.405^{* *}$ \\
\hline \multirow[t]{2}{*}{12} & G & & & & & & & & & & & & $0.400^{* *}$ \\
\hline & $P$ & & & & & & & & & & & & $0.386^{* *}$ \\
\hline
\end{tabular}

*: Significant at $(p=0.05) ; * *$ Significant at $(p=0.01) ; 1$ : Plant height $(\mathrm{cm}) ; 2$ : Plant spread $(\mathrm{cm}) ; 3$ : No. of primary branches plant $^{-1}$; 4: Number of secondary branches plant ${ }^{-1} ; 5$ : Number of leaves plant ${ }^{-1} ; 6$ : Days to $50 \%$ flowering; 7 : No. of flowers plant $^{-1}$; 8: Flower diameter $(\mathrm{cm})$; 9: Fresh flower weight plant ${ }^{-1}(\mathrm{~kg})$; 10: Dry flower weight plant ${ }^{-1}(\mathrm{~kg})$; 11: Flowering duration (days); 12: Yield ha-1 $(\mathrm{t})$; 13: Xanthophyll content

at genotypic level but significant positive correlation at phenotypic level was recorded which is supported by the finding of Panwar et al. (2013) in African marigold and Namita et al. (2009) in marigold. Dry flower weight exerted highly significant positive correlation with flower yield hectare ${ }^{-1}$ at both genotypic and phenotypic level and significantly positive correlation with flowering duration at genotypic and phenotypic level. Highly significant positive association of flowering duration was recorded with xanthophyll content at genotypic level and phenotypic level. Whereas, positive highly significant correlation at genotypic level but significant at phenotypic level was observed for flower yield ha-1. Flower yield ha-1 had highly positive significant association with xanthophyll content at genotypic and phenotypic levels. Therefore, selection for any of the traits showing significant positive correlation among themselves would improve other traits and thus improve the flower yield. Further the selection based on traits having strong positive association would result in improving the flower yield and the hybridization of genotypes possessing combination of such traits may be useful for obtaining elite marigold plants.

\subsection{Path coefficient analysis}

The genotypic and phenotypic correlation coefficient of flower yield and its components were broken down into direct and indirect effect and taking total number of flowers plant ${ }^{-1}$ as dependent variable, rest of the character were taken as independent variables (Table 2 and 3 ).

\subsection{Genotypic path analysis}

In path-coefficient analysis, at genotypic level, fresh weight of flowers plant ${ }^{-1}$ (2.677) expressed highest positive direct effect on number of flowers plant ${ }^{-1}$ followed by xanthophyll 


\begin{tabular}{|c|c|c|c|c|c|c|c|c|c|c|c|c|c|}
\hline $\begin{array}{l}\text { Sl. } \\
\text { No. }\end{array}$ & 1 & 2 & 3 & 4 & 5 & 6 & 8 & 9 & 10 & 11 & 12 & 13 & $\begin{array}{l}\text { Correlation } \\
\text { with no. of } \\
\text { flowers plant }{ }^{-1}\end{array}$ \\
\hline 1. & 0.208 & -0.051 & -0.074 & 0.062 & -0.221 & -0.003 & -0.042 & -0.613 & 0.119 & -0.077 & 0.208 & -0.034 & $-0.518^{* *}$ \\
\hline 2. & -0.056 & 0.190 & 0.018 & 0.012 & -0.031 & -0.002 & 0.048 & 0.149 & -0.123 & 0.010 & -0.049 & -0.044 & 0.122 \\
\hline 3. & 0.091 & -0.021 & -0.168 & 0.108 & -0.335 & -0.001 & -0.035 & 1.256 & -0.345 & -0.171 & -0.424 & 0.040 & -0.007 \\
\hline 4. & 0.077 & 0.014 & -0.109 & 0.166 & -0.336 & -0.001 & -0.024 & 1.310 & -0.453 & -0.112 & -0.443 & 0.013 & 0.105 \\
\hline 5. & 0.102 & 0.013 & -0.125 & 0.124 & -0.451 & -0.001 & 0.009 & 1.234 & -0.424 & -0.236 & -0.417 & 0.005 & -0.169 \\
\hline 6. & 0.073 & 0.054 & -0.024 & 0.018 & -0.036 & -0.008 & 0.061 & -1.242 & 0.353 & 0.035 & 0.417 & -0.048 & $-0.346^{*}$ \\
\hline 8. & 0.063 & -0.067 & -0.043 & 0.029 & 0.028 & 0.004 & -0.138 & 0.857 & -0.335 & 0.076 & -0.285 & 0.097 & $0.287^{*}$ \\
\hline 9. & -0.048 & 0.011 & -0.079 & 0.081 & -0.208 & 0.004 & -0.044 & 2.677 & -0.820 & -0.173 & -0.904 & 0.130 & $0.626^{* *}$ \\
\hline 10. & -0.028 & 0.027 & -0.066 & 0.085 & -0.217 & 0.003 & -0.052 & 2.488 & -0.883 & -0.161 & -0.842 & 0.079 & $0.434^{* *}$ \\
\hline 11. & 0.034 & -0.004 & -0.062 & 0.040 & -0.228 & 0.001 & 0.022 & 0.990 & -0.303 & -0.467 & -0.335 & 0.143 & -0.171 \\
\hline 12. & -0.048 & 0.010 & -0.079 & 0.082 & -0.209 & 0.004 & -0.044 & 2.683 & -0.824 & -0.174 & -0.902 & 0.130 & $0.630^{* *}$ \\
\hline 13. & -0.022 & -0.026 & -0.021 & 0.007 & -0.006 & 0.001 & -0.041 & 1.068 & -0.214 & -0.205 & -0.361 & 0.325 & $0.504^{* *}$ \\
\hline
\end{tabular}

Residual effect 0.05734; Diagonal value - direct effect

Table 3: Phenotypic path coefficient analysis of different characters on number of flowers plant ${ }^{-1}$ in African marigold genotypes

\begin{tabular}{lccccccccccccc}
\hline $\begin{array}{l}\text { Sl. } \\
\text { No. }\end{array}$ & 1 & 2 & 3 & 4 & 5 & 6 & 8 & 9 & 10 & 11 & 12 & 13 & $\begin{array}{c}\text { Correlation } \\
\text { with no. of } \\
\text { flowers plant }\end{array}$ \\
\hline 1. & -0.077 & -0.027 & -0.018 & 0.034 & -0.118 & 0.007 & -0.003 & -0.430 & 0.056 & -0.073 & 0.197 & -0.037 & $-0.488^{* *}$ \\
2. & 0.017 & 0.119 & 0.006 & 0.005 & -0.015 & 0.007 & 0.002 & 0.114 & -0.054 & 0.001 & -0.057 & -0.045 & 0.099 \\
3. & -0.032 & -0.016 & -0.045 & 0.059 & -0.181 & 0.002 & -0.002 & 0.849 & -0.161 & -0.134 & -0.386 & 0.041 & -0.005 \\
4. & -0.026 & 0.005 & -0.027 & 0.100 & -0.181 & 0.003 & -0.001 & 0.930 & -0.210 & -0.085 & -0.422 & 0.014 & 0.100 \\
5. & -0.035 & 0.007 & -0.031 & 0.069 & -0.261 & 0.001 & 0.001 & 0.872 & -0.202 & -0.192 & -0.396 & 0.004 & -0.163 \\
6. & -0.022 & 0.034 & -0.005 & 0.011 & -0.012 & 0.023 & 0.003 & -0.693 & 0.139 & -0.014 & 0.319 & -0.041 & -0.257 \\
8. & -0.023 & -0.026 & -0.008 & 0.011 & 0.010 & -0.007 & -0.010 & 0.520 & -0.143 & 0.048 & -0.244 & 0.088 & 0.214 \\
9. & 0.016 & 0.007 & -0.019 & 0.046 & -0.112 & -0.008 & -0.003 & 2.027 & -0.397 & -0.146 & -0.924 & 0.137 & $0.625^{* *}$ \\
10. & 0.010 & 0.015 & -0.017 & 0.048 & -0.121 & -0.007 & -0.003 & 1.836 & -0.438 & -0.133 & -0.834 & 0.085 & $0.441^{* *}$ \\
11. & -0.013 & 0.001 & -0.014 & 0.020 & -0.120 & 0.001 & 0.001 & 0.707 & -0.140 & -0.419 & -0.319 & 0.144 & -0.152 \\
12. & 0.016 & 0.007 & -0.019 & 0.046 & -0.111 & -0.008 & -0.003 & 2.019 & -0.394 & -0.144 & -0.928 & 0.137 & $0.618^{* *}$ \\
13. & 0.008 & -0.015 & -0.005 & 0.004 & -0.003 & -0.003 & -0.002 & 0.786 & -0.105 & -0.170 & -0.358 & 0.354 & $0.491^{* *}$ \\
\hline
\end{tabular}

Residual effect 0.16691; Diagonal value - direct effect

content (0.325), plant height (0.208), plant spread (0.190) and number of secondary branches plant ${ }^{-1}(0.166)$. The associations of these characters with number of flowers plant $^{-1}$ are in desirable direction and selection of these traits may ultimately improve the yield. Similar results were quoted by Anuja and Jahnavi (2012) and Usha bharti et al. (2014) in African marigold. The positive indirect effect of plant height on number of flowers plant ${ }^{-1}$ was observed through number of leaves plant ${ }^{-1}(0.102)$ followed by number of primary branches plant $^{-1}(0.091)$, no. of secondary branches plant ${ }^{-1}$
(0.077), days to $50 \%$ flowering (0.073), flower diameter (0.063) and flowering duration (0.034). Plant spread had positive indirect effect on number of flowers plant ${ }^{-1}$ through days to $50 \%$ flowering $(0.054)$ followed by dry weight of flowers plant $^{-1}(0.027)$, number of secondary plant ${ }^{-1}$ branches (0.014), number of leaves plant ${ }^{-1}(0.013)$, fresh flower weight plant ${ }^{-1}$ (0.011) and yield ha-1 $(0.010)$.

The positive indirect contribution of number of secondary branches plant ${ }^{-1}$ on number of flowers plant ${ }^{-1}$ was estimated through number of leaves plant ${ }^{-1}(0.124)$, number of primary 
branches plant ${ }^{-1}(0.108)$, dry flower weight plant ${ }^{-1}(0.085)$, yield hectare ${ }^{-1}(0.082)$, fresh flower weight plant ${ }^{-1}(0.081)$, plant height (0.062), flowering duration (0.040), diameter of flower (0.029), days to $50 \%$ flowering (0.018), plant spread (0.012) and xanthophyll content (0.007).

Number of leaves plant ${ }^{-1}$ exhibited positive indirect effect on number of flowers plant ${ }^{-1}$ via diameter of flower (0.028). It was estimated that days to $50 \%$ flowering exhibited positive indirect effect through flower diameter (0.004), fresh flower weight plant ${ }^{-1}(0.004)$, yield $h^{-1}(0.004)$ and xanthophyll content (0.001). The positive indirect effect of flower diameter on number of flowers plant ${ }^{-1}$ was observed through days to $50 \%$ flowering $(0.061)$, plant spread $(0.048)$, flowering duration (0.022) and number of leaves plant ${ }^{-1}(0.009)$. Fresh flower weight plant ${ }^{-1}$ had positive indirect effect on number of flowers plant ${ }^{-1}$ through yield hectare ${ }^{-1}$ (2.683), dry flower weight plant ${ }^{-1}(2.488)$, number of secondary branches plant $^{-1}$ (1.310), number of primary branches plant ${ }^{-1}$ (1.256), number of leaves plant ${ }^{-1}(1.234)$, xanthophyll content (1.068), flowering duration (0.990), diameter of flower (0.857) and plant spread (0.149). Dry flower weight plant ${ }^{-1}$ had positive indirect effect on number of flowers plant ${ }^{-1}$ through days to $50 \%$ flowering $(0.353)$, plant height $(0.119)$. The positive indirect effect of flowering duration on number of flowers plant $^{-1}$ was observed through diameter of flower (0.076), days to $50 \%$ flowering $(0.035)$ and plant spread (0.010). The positive indirect contribution of yield hectare ${ }^{-1}$ on number of flowers plant ${ }^{-1}$ was estimated through days to $50 \%$ flowering (0.417) and plant height (0.208). Similar results were recorded by Vishnupriy et al. (2015) in local marigold and Bharathi et al. (2014) in african marigold.

Xanthophyll content had positive indirect effect on number of flowers plant ${ }^{-1}$ via flowering duration (0.143), fresh flower weight plant ${ }^{-1}(0.130)$, yield hectare ${ }^{-1}(0.130)$, diameter of flower (0.097), dry flower weight plant ${ }^{-1}$ (0.079), number of primary branches plant ${ }^{-1}(0.040)$, number of secondary branches plant $^{-1}(0.013)$ and number of leaves plant ${ }^{-1}(0.005)$.

\subsection{Phenotypic path analysis}

At phenotypic level, fresh flower weight plant ${ }^{-1}$ (2.027) showed high positive direct effect on number of flowers plant ${ }^{-1}$ followed by xanthophyll content (0.354), plant spread (0.119), number of secondary branches plant ${ }^{-1}(0.100)$ and days to $50 \%$ flowering $(0.023)$. The positive indirect effect of plant height on number of flowers plant ${ }^{-1}$ was observed through plant spread (0.017), fresh flower weight plant ${ }^{-1}(0.016)$, yield ha $^{-1}(0.016)$, dry flower weight plant ${ }^{-1}(0.010)$ and xanthophyll content (0.008). Plant spread had positive indirect effect on number of flowers plant ${ }^{-1}$ through days to $50 \%$ flowering (0.034), followed by dry flower weight plant ${ }^{-1}(0.015)$, number of leaves plant ${ }^{-1}(0.007)$, fresh flower weight plant ${ }^{-1}(0.007)$, yield hectare ${ }^{-1}(0.007)$, no. of secondary branches plant ${ }^{-1}$ (0.005) and flowering duration (0.001). Primary branches plant $^{-1}$ had positive indirect effect on number of flowers plant ${ }^{-1}$ through plant spread (0.006). Number of secondary branches plant $^{-1}$ exhibited positive indirect effect on number of flowers plant $^{-1}$ via number of leaves plant ${ }^{-1}(0.069)$, number of primary branches plant ${ }^{-1}$ (0.059), dry flower weight plant ${ }^{-1}(0.048)$, fresh flower weight plant ${ }^{-1}(0.046)$, yield hectare ${ }^{-1}(0.046)$, plant height (0.034), flowering duration (0.020), days to $50 \%$ flowering (0.011), diameter of flower (0.011), plant spread $(0.005)$ and xanthophyll content (0.004). The positive indirect effect of number of leaves plant ${ }^{-1}$ on number of flowers plant ${ }^{-1}$ observed via diameter of flower (0.010). It was estimated that days to $50 \%$ flowering exhibited positive indirect effect through plant height (0.007), plant spread $(0.007)$, number of secondary branches plant ${ }^{-1}(0.003)$, number of primary branches plant ${ }^{-1}(0.002)$, number of leaves plant ${ }^{-1}(0.001)$, flowering duration (0.001). The positive indirect effect of flower diameter on number of flowers plant ${ }^{-1}$ was observed through days to $50 \%$ flowering $(0.003)$, plant spread (0.002) and flowering duration (0.001). Fresh flower weight plant ${ }^{-1}$ had positive indirect effect on number of flowers plant ${ }^{-1}$ through yield ha-1 (2.019), dry flower weight plant ${ }^{-1}$ (1.836), number of secondary branches plant ${ }^{-1}(0.930)$, number of leaves plant $^{-1}(0.872)$, number of primary branches plant ${ }^{-1}(0.849)$, xanthophyll content (0.786), flowering duration (0.707), diameter of flower (0.520) and plant spread (0.114). Dry flower weight plant ${ }^{-1}$ had positive indirect effect on number of flowers plant ${ }^{-1}$ through days to $50 \%$ flowering $(0.139)$ and plant height (0.056). The positive indirect effect of flowering duration on number of flowers plant ${ }^{-1}$ was observed through diameter of flower (0.048) and plant spread (0.001). Yield hectare $^{-1}$ had positive indirect effect through days to $50 \%$ flowering (0.319) and plant height (0.197). Xanthophyll content had positive indirect effect on number of flowers plant $^{-1}$ through flowering duration (0.144), fresh flower weight plant $^{-1}(0.137)$, yield ha ${ }^{-1}(0.137)$, diameter of flower $(0.088)$, dry flower weight plant ${ }^{-1}(0.085)$, number of primary branches plant $^{-1}(0.041)$, number of secondary branches plant ${ }^{-1}(0.014)$ and number of leaves plant ${ }^{-1}(0.004)$.

\section{Conclusion}

No. of flowers plant ${ }^{-1}$ exerted highly significant positive correlation with fresh flower weight plant ${ }^{-1}$ (yield plant ${ }^{-1}$ ), dry flower weight plant ${ }^{-1}$, flower yield ha-1 and xanthophyll content at genotypic and phenotypic level. In pathcoefficient analysis revealed that, at genotypic level, fresh weight of flowers plant ${ }^{-1}$ (yield plant $^{-1}$ ) expressed highest positive direct effect on number of flowers plant ${ }^{-1}$ followed by xanthophyll content, plant height, plant spread and number of secondary branches plant ${ }^{-1}$.

\section{Refrences}

Anonymous, 2014. Chhattisgarh Database, Directorate of horticulture. government of chhattisgarh, raipur.

Anuja, S., Jahnavi, K., 2012. Variability, heritability and genetic advance studies in French marigold (Tagetes 
patula L.). The Asian Journal of Horticulture 7(2), 362364.

Bharathi, T., Jawaharlal, M., 2014. Evaluation of African marigold (Tagetes erecta. L). genotypes for growth and flower yield under Coimbatore conditions. Trends in Biosciences 7(16), 2197-2201.

Bharati Usha, T., Jawaharlal, M., Kannan, M., Anivannan, N., Raveendran, M., 2014. Correlation and path analysis in African marigold (Tagetes erecta L.) 9(4), 1673-1676.

Gobade, N., Badge, S., Patil, S., Gormade, G., 2017. Genetic Variability Studies for Various Quantitative Traits in Marigold. International Journal of Pure and Applied Biosciences 5(2), 751-757.

Karuppaiah, P., Kumar, P.S., 2010. Correlation and path analysis in African marigold (Tagetes erecta L.). Electronic Journal of Plant Breeding 1(2), 217-220.

Kavitha, R., Anburani, A., 2010. Genetic variability in African marigold. The Asian Journal of Horticulture 5 (2), 344-346.

Kumar, A., Pratap, B., Beer, K., 2014. Studies on Genetic variability and character association in French marigold (Tagetes patula L.). Trends in Biosciences 7(2), 122-124.

Manjula, B.S., Nataraj, S.K., 2016. Genetic Correlation And Path Coefficient Analysis In Dahlia (Ahlia (Dahlia Variabilis Ariabilis L.) Genotypes Under Hill Zone Of Karnataka, The Bioscane 11(2), 1089-1092.

Panwar, S., Singh, K.P., Janakiram, T., Namita, 2013. Genetic variability, heritability and genetic advance in African marigold (Tagetes erecta L.) genotypes. Progressive Horticulture, 45(1), 135-140.

Vishnupriy, A.K., Jawaharlal, M., Manivannan, N., 2015. Variability studies in african marigold. an international quarterly Journal of life science 10(1), 407-409. 